\title{
Interleukin-8 promotes prostate cancer bone metastasis through upregulation of bone sialoprotein
}

\author{
BAOHAO LIU, MENG XU, ZHONGQING GUO, JIAJIE LIU, XU CHU and HUAMAO JIANG
}

Department of Urology, The First Affiliated Hospital of Jinzhou Medical University, Jinzhou, Liaoning 121000, P.R. China

Received May 9, 2018; Accepted February 18, 2019

DOI: $10.3892 / \mathrm{ol} .2019 .10138$

\begin{abstract}
The aim of the present study was to investigate whether interleukin-8 (IL-8) enhances the ability of prostate cancer bone metastasis by influencing the coding level of bone sialoprotein (BSP). Cultured prostate cancer cell lines LNCaP (androgen dependent) and DU145 (androgen independent) were divided into three groups: IL-8 treatment group; IL-8 receptor inhibitor (SB225002) treatment group; and control group. Western blotting and reverse transcription-quantitative polymerase chain reaction (RT-qPCR) were used to detect BSP protein and mRNA expression levels. Matrigel and bone adhesion experiments were used to detect the invasiveness of cancer cells and bone adhesion changes. Compared with the control group, western blotting and RT-qPCR results indicated that BSP protein and mRNA levels in LNCaP and DU145 were significantly upregulated following IL-8 treatment. Matrigel experiments indicated that following IL-8 treatment, the invasiveness of LNCaP and DU145 cells was significantly increased. The results of bone adhesion experiments indicated that following IL-8 treatment, the number of DU145 cells adhered to the surface of the bone was increased, compared with the control group. Following treatment of both cell lines with SB225002, western blotting and RT-qPCR results indicated that the expression levels of BSP protein and mRNA were significantly downregulated. Matrigel experiments indicated that following SB225002 treatment, the invasiveness of LNCaP and DU145 cells was significantly reduced. The number of DU145 cells adhered to the surface of the bone was reduced, compared with the untreated group. Therefore, IL-8 may promote prostate cancer bone metastasis by enhancing BSP regulation.
\end{abstract}

\section{Introduction}

Prostate cancer $(\mathrm{PCa})$ is the most common malignancy in American men $(1,2)$. Despite the fact that castration therapy

Correspondence to: Professor Huamao Jiang, Department of Urology, The First Affiliated Hospital of Jinzhou Medical University, 5 Renmin Road, Jinzhou, Liaoning 121000, P.R. China

E-mail: lyyyjhm@163.com

Key words: prostate cancer, bone metastasis, interleukin-8, bone sialoprotein can significantly inhibit tumor growth, $>60 \%$ of patients experience relapse (1), and androgen-dependent tumor cells become subsequently castration-resistant and prone to distant metastasis (2). Bone metastasis is the leading cause of mortality in patients with PCa $(2,3)$. Therefore, investigations of the molecular mechanism of distant metastasis, as well as the early detection and prevention of its occurrence, are important to improve the prognosis and extend the survival time of patients with PCa.

As an osteolytic marker, bone sialoprotein (BSP), serves an important role in bone metastasis of malignant tumor types (4). During the course of tumor invasion, BSP activates specific metalloproteinases that enhance cancer cell ability to hydrolyze the extracellular matrix (5). BSP binding to integrins contributes to breast cancer cell metastasis, particularly bone metastasis (6). In addition, BSP-transfected breast cancer cells exhibit increased primary tumor growth following injection into the mammary fat pad of nude mice (5). Furthermore, it induces matrix metalloproteinase-2 (MMP-2) to accumulate on the cell surface $(5,6)$, enhancing its activity and thereby promoting the degradation of extracellular matrix and enhancing cancer invasion (6). Interleukin-8 (IL-8) is a cytokine that has been indicated to serve an important role in the growth and invasion of PCa (7-9). SB225002 is a specific C-X-C Motif Chemokine Receptor 2 (CXCR2) receptor antagonist, and studies have reported that SB225002 induces ovarian cancer cell apoptosis, and cell death and cell cycle arrest in acute lymphoblastic leukemia cells $(10,11)$. However, only few studies have described the inhibitory effect of SB225002 on cancer cell invasion and metastasis. In the present study, the effects of IL-8 and IL-8 receptor antagonist SB225002 (10-12) on BSP were investigated, which confirmed that IL-8 promotes bone metastasis of PCa by increasing BSP expression.

\section{Materials and methods}

Cell culture and drugs. Cultured PCa cells, LNCaP (androgen dependent) and DU145 (androgen independent), and the immortalized prostate epithelial cell line RWPE-1 were purchased from the iCell Bioscience, Inc. (Shanghai, China). Tumor cells, LNCaP and DU145, were cultured in RPMI-1640 medium (Gibco; Thermo Fisher Scientific, Inc., Waltham, MA, USA) containing 10\% fetal bovine serum (FBS; Gibco; Thermo Fisher Scientific, Inc.), penicillin (100 U/ml) and streptomycin $(100 \mathrm{U} / \mathrm{ml})$ and placed at $37^{\circ} \mathrm{C}$ in a humidified 
incubator containing 5\% $\mathrm{CO}_{2}$. RWPE-1 cells were cultured in Dulbecco's modified Eagle's medium (Gibco; Thermo Fisher Scientific, Inc.) containing 10\% FBS, penicillin (100 U/ml) and streptomycin $(100 \mathrm{U} / \mathrm{ml})$ and placed at $37^{\circ} \mathrm{C}$ in a humidified incubator containing $5 \% \mathrm{CO}_{2}$. Tumor cells $\mathrm{LNCaP}$ and DU145 in the experimental groups were treated with recombinant human IL-8 protein at10 $\mathrm{ng} / \mathrm{ml}$ for $48 \mathrm{~h}(9,10)$, which had no effect on cell proliferation (Gibco; Thermo Fisher Scientific, Inc.) or IL-8 receptor antagonist SB225002 (Selleck Chemicals, Houston, TX, USA) at $37^{\circ} \mathrm{C}$.

MTT assay. An MTT assay was used in order to provide a quantitative measure of the number of cells with metabolically active mitochondria, as it is based on the mitochondrial reduction of a tetrazolium bromide salt [3-(4,5-dimethylthiazol2-yl)-2,5-diphenyltetrazolium bromide] $(13,14)$. DU145 and LNCaP cells $(3,000$ cells/well) were plated in triplicate in 96-well culture plates in RPMI-1640 containing 10\% FBS and subsequently incubated with different concentrations of the IL-8 receptor inhibitor SB225002 (0.2, 0.4, 0.8, 1.6, 3.2, $6.4 \mu \mathrm{M}$ and control dimethyl sulfoxide (DMSO) $0.01 \%$ ) at $37^{\circ} \mathrm{C}$. At the end of the treatment $(24,48$ or $72 \mathrm{~h}$ following SB225002 incubation), the medium was removed, formazan was dissolved in DMSO, an MTT assay was performed, and the absorbance rate was observed at a wavelength of $570 \mathrm{~nm}$.

Western blotting. At the end of the treatment, LNCaP and DU145 $\left(2 \times 10^{6}\right.$ cells $\left./ \mathrm{ml}\right)$ were harvested and washed in triplicate with cold PBS. The cells were lysed in ice-cold lysis buffer $(50 \mathrm{mM}$ Tris- $\mathrm{HCl}$, pH 7.4, $250 \mathrm{mM} \mathrm{NaCl}, 50 \mathrm{mM} \mathrm{NaF}, 5 \mathrm{mM}$ EDTA, $0.1 \%$ Triton $\mathrm{X}-100$ and $0.1 \mathrm{mM} \mathrm{Na}_{3} \mathrm{VO}_{4}$ ). Following centrifugation at $12,000 \mathrm{x}$ g for $15 \mathrm{~min}$ at $4^{\circ} \mathrm{C}$ to remove all organelles, the supernatants were removed, and the protein levels were estimated using a Super-Bradford Protein Assay kit (CoWin Biosciences Co., Ltd., Beijing, China), according to the manufacturer's protocol. Equal amounts of proteins ( $20 \mu \mathrm{g} /$ lane) were denatured in SDS-PAGE buffer, subjected to SDS-PAGE on a $12 \%$ Tris-glycine gel and transferred onto polyvinylidene fluoride membranes. Membranes were blocked with 5\% skimmed milk in TBS containing $0.1 \%$ Tween-20 for $1 \mathrm{~h}$ at room temperature. After washing with TBST three times, membranes were co-incubated with the primary antibody against BSP (1:500; cat. no. BA2329; Boster Biological Technology, Pleasanton, CA, USA) MMP-2 (1:500; cat. no. bs-4599R Biosynthesis Biotechnology Co., Ltd. Beijing, China) and GAPDH (1:500; cat. no. bs-0755R Biosynthesis Biotechnology Co.) overnight at $4^{\circ} \mathrm{C}$ in TBST. After incubation with horseradish peroxidase goat anti-rabbit immunoglobulin G (1:10,000; cat. no. BA1055; Boster Biological Technology) in TBST at room temperature for $60 \mathrm{~min}$, bands were detected using enhanced chemiluminescence detection system (APG Bio Ltd., Shanghai, China). Primary antibody against BSP was obtained from Wuhan Boster Biological Technology, Ltd. (Wuhan, China). Primary antibodies against MMP-2 and GAPDH were purchased from Beijing Biosynthesis Biotechnology Co., Ltd. (Beijing, China). ImageJ 1.0 (National Institutes of Health, Bethesda, MD, USA) was used for quantitative analysis of the bands. To account for any differences in loading, target band densitometries were divided by GAPDH densitometries obtained from the same lane.
Reverse transcription-quantitative polymerase chain reaction $(R T-q P C R)$. Following the treatment of LNCaP and DU145 cells with IL-8 or SB225002, RNAiso Plus (Takara Bio, Inc., Otsu, Japan) was used to extract total RNA, which was reverse transcribed into cDNA using a PrimeScript ${ }^{\mathrm{TM}}$ RT reagent kit with gDNA Eraser (Takara Bio, Inc.), followed by PCR with SYBR ${ }^{\circledR}$ Green RT-PCR Master mix (Takara Bio, Inc.), according to the manufacturer's protocols. The primers used for RT-qPCR were synthesized by Shenyang Maigejin Biological Technology Co., Ltd. The primer sequences were the following: BSP upstream primer, 5'-TTCCAGTTC AGGGCAGTAGT-3', and BSP downstream primer, 5'-AGC CCAGTGTTGTAGCAGAAA-3; MMP-2 upstream primer, 5'-ATA ACCTGGATGCCGTCGT-3', and MMP-2 downstream primer, 5'-AGGCACCCTTGAAGAAGTAGC-3'; and GAPDH upstream primer, 5'-CTGGAACGGTGAAGGTGA CA-3', and GAPDH downstream primer 5'-AAGGGACTT CCTGTAACAACGCA-3'. qPCR was carried out using SYBR Premix Ex Taq ${ }^{\mathrm{TM}}$ (Takara Biotechnology, Co., Ltd., Dalian, China). qPCR thermocycling was performed as follows: Pre-deformation $95^{\circ} \mathrm{C}$ for $10 \mathrm{~min}, 1$ cycle; denaturation $95^{\circ} \mathrm{C}$ for $15 \mathrm{sec}$ and annealing $60^{\circ} \mathrm{C}$ for $60 \mathrm{sec}, 40$ cycles. The reactions were performed in a 96 -well plate using a preheated real-time instrument (ABI 7500HT; Applied Biosystems Life Technologies; Thermo Fisher Scientific, Inc.). The relative expression levels were quantified and analyzed using Bio-Rad iCycler iQ software 3.1 (Bio-Rad Laboratories, Inc., Hercules, CA, USA). The expression level of BSP and MMP-2 were calculated using the $2^{-\Delta \Delta \mathrm{Cq}}$ method (15).

Bone chip adhesion assay. The PCa cell line DU-145 was pre-treated with low-concentrations of IL-8 $(2 \mathrm{ng} / \mathrm{ml})$ or SB225002 $(0.08 \mu \mathrm{mol} / 1)$ at $37^{\circ} \mathrm{C}$ for $24 \mathrm{~h}$. All surgical procedures were performed in accordance to the guidelines of the Laboratory Animal Ethics Committee Jinzhou Medical University (review no. 2016007; Jinzhou, China). The 12 mice were housed in sterile laminar flow rooms at $25^{\circ} \mathrm{C}$ and $50 \%$ humidity. Mice had free access to food and water during the whole study and were submitted to $12 \mathrm{~h}$ light/dark cycles. The mice were sacrificed by $\mathrm{CO}_{2}$ asphyxiation (10 30\% of the container volume per minute). Entire skulls were removed from specific-pathogen-free (SPF) male mice weighing 20-22 g (6-8 weeks old; Jinzhou Medical University, Jinzhou, China). Entire skulls were removed from SPF male mice (Jinzhou Medical University), soaked in penicillin and streptomycin $(1,000 \mathrm{U} / \mathrm{ml})$, and treated with PBS containing $100 \mathrm{U} / \mathrm{ml}$ collagenase and $0.25 \%$ trypsin for $2 \mathrm{~h}$ at $37^{\circ} \mathrm{C}(14)$. A total of $0.5 \mathrm{ml}$ of $0.1 \%$ agar was subsequently added to each well of 24-well plates to secure the bone chips. Once the agar solidified, RPMI-1640 was added, and the plates were incubated at $37^{\circ} \mathrm{C}$ for $30 \mathrm{~min}$. The pre-treated cells were digested and seeded into 24 -well plates, with $\sim 1 \times 10^{5}$ cells added to each well. Subsequently, $10 \mathrm{ng} / \mathrm{ml} \mathrm{IL}-8$, which had no effect on the proliferation of DU145 and LNCaP cells (data not shown) was added to the IL-8 treatment group, and $0.4 \mu \mathrm{mol} / 1 \mathrm{SB} 225002$ was added to the SB225002 treatment group, followed by an incubation with $5 \% \mathrm{CO}_{2}$ at $37^{\circ} \mathrm{C}$ for $24 \mathrm{~h}$. Following bone chip removal, the cells were washed with PBS three times and fixed in $4 \%$ paraformaldehyde at room temperature for $24 \mathrm{~h}$. Following this, the membranes were permeabilized with $0.2 \%$ 

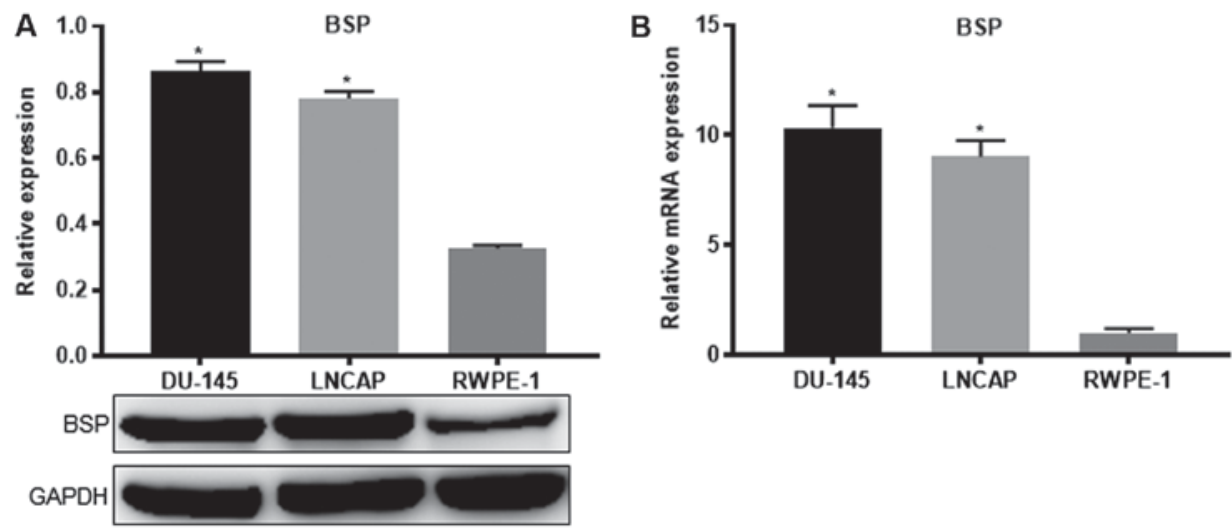

Figure 1. Expression of BSP protein and BSP mRNA in PCa cell lines. (A) BSP protein expression levels in normal prostate cells and in PCa cell lines $(\mathrm{P}=0.003)$. (B) BSP mRNA expression levels in normal and $\mathrm{PCa}$ cell lines $(\mathrm{P}=0.004)$. ${ }^{*} \mathrm{P}<0.05$. BSP, bone sialoprotein; $\mathrm{PCa}$, prostate cancer.

Triton X-100, after which the cells stained with Coomassie brilliant blue $(100 \mathrm{mg} / \mathrm{l})$ at room temperature for $10 \mathrm{~min}$ and digested with trypsin-EDTA. A microplate reader was used to measure optical density at a wavelength of $570 \mathrm{~nm}$.

Matrigel assay. A Transwell chamber was used to perform a cell invasion assay. The upper chamber was pre-plated with Matrigel (BD Biosciences, San Jose, CA, USA), which was allowed to solidify at $37^{\circ} \mathrm{C}$ for $4 \mathrm{~h}$. Cells were harvested and $200 \mu \mathrm{l}$ cell suspension $\left(2 \times 10^{5}\right.$ cells $\left./ \mathrm{ml}\right)$ was added to the upper Transwell chamber, while $500 \mu 1$ RPMI-1640 containing 20\% FBS was added to the lower chamber. Subsequently, $0.4 \mu \mathrm{mol} / 1$ SB225002 was added to the SB225002 treatment group, and $10 \mathrm{ng} / \mathrm{ml} \mathrm{IL-8}$ was added to the IL-8 treatment group. The chamber was placed at $37^{\circ} \mathrm{C}$ with $5 \% \mathrm{CO}_{2}$ for $48 \mathrm{~h}$. After incubation, cells in the upper part of the Transwell were removed with a cotton swab, and the chamber was washed with PBS. Cells were fixed with $4 \%$ paraformaldehyde at room temperature for $15 \mathrm{~min}$ and stained with $0.1 \%$ crystal violet for $10 \mathrm{~min}$. Cells were counted under a light microscope (magnification, x400; Olympus IX51; Olympus Corp., Tokyo, Japan).

Statistics analysis. All data analyses were performed using Microsoft Office Excel 2016 (Microsoft Corporation, Redmond, WA, USA) and GraphPad software 7.04 (GraphPad Software, Inc., La Jolla, CA, USA). Data are presented as the mean \pm standard deviation of the indicated number of experiments. Statistical analysis was performed with unpaired Student's t-test and one-way analysis of variance with Tukey's post hoc test. $\mathrm{P}<0.05$ was considered to indicate a statistically significant difference.

\section{Results}

BSP expression in PCa and normal prostate cells. Western blotting and RT-qPCR were performed to determine BSP expression in the non-androgen-dependent $\mathrm{PCa}$ cell line DU-145, the androgen-dependent PCa cell line LNCAP, and in normal prostate cells. The results indicated that BSP mRNA and protein expression levels were significantly increased in the two PCa cell lines, compared with the normal prostate cells (Fig. 1).

BSP expression following IL-8 treatment. Recombinant human IL-8 (10 ng/ml) was used to treat the two PCa cell lines for $48 \mathrm{~h}$, after which western blotting and RT-qPCR were performed to determine BSP expression level. The IL-8 treatment significantly increased the mRNA and protein levels of BSP in the two PCa cell lines, compared with the control group. IL-8 $(10 \mathrm{ng} / \mathrm{ml})$ had no effect on the proliferation of DU145 and LNCaP cells (data not shown). The expression level of BSP protein in the IL-8 treatment group was increased, compared with the control group, which indicated that IL-8 promotes BSP expression in PCa cells $(\mathrm{P}<0.05$; Fig. 2$)$.

Inhibitory time and concentration of SB225002, IL-8 receptor inhibitor, in the two PCa cell lines. SB225002 is a specific inhibitor of the IL-8 receptor C-X-C motif chemokine receptor 2 (CXCR2) (16). A total of six concentrations were assayed $(0.2,0.4,0.8,1.6,3.2$ and $6.4 \mu \mathrm{mol} / 1)$, with 5 replicates tested for each concentration. The results indicated that DU145 and LNCaP cell proliferation was inhibited in a concentration and time-dependent manner following treatment with SB225002. The relative cell viability curve of DU145 demonstrated that the effect of SB225002 on cell viability was statistically significant when cultured for $72 \mathrm{~h}$ at $0.2 \mu \mathrm{mol} / 1$ compared with the control group. After 24 or $48 \mathrm{~h}$ of culture, cell viability was significantly decreased following treatment with 6.4 or $0.8 \mu \mathrm{mol} / 1$, respectively (Fig. 3A). The relative cell viability curve of $\mathrm{LNCaP}$ demonstrated that the effect of SB225002 on cell viability was statistically significant when cultured for $72 \mathrm{~h}$ and at $0.4 \mu \mathrm{mol} / 1$ compared with control group. After 24 or $48 \mathrm{~h}$ of culture, the concentration of SB225002 required to induce a significant toxicity were 6.4 or $1.6 \mu \mathrm{mol} / 1$, respectively (Fig. 3B). SB225002 $(0.4 \mu \mathrm{mol} / \mathrm{l})$ had no effect on the proliferation of DU145 and LNCaP cells following $48 \mathrm{~h}$ of treatment (Fig. 3).

Adhesion of PCa cells on bone chip surfaces and PCa invasion following SB225002 treatment. For the non-androgen-dependent PCa cell line DU-145, bone adhesion was significantly reduced following SB225002 $(0.4 \mu \mathrm{mol} / \mathrm{l})$ treatment, verified by the deceased number of DU-145 cells adhering to the bone chip surface. The bone chips were stained with Coomassie brilliant blue, and the spindle-shaped dark blue spots in the image were cells adhering to the bone chip surfaces (Fig. 4). Furthermore, the Transwell assay was used to validate the effect of SB225002 on PCa cell invasive ability. Following $48 \mathrm{~h}$ of treatment, the 

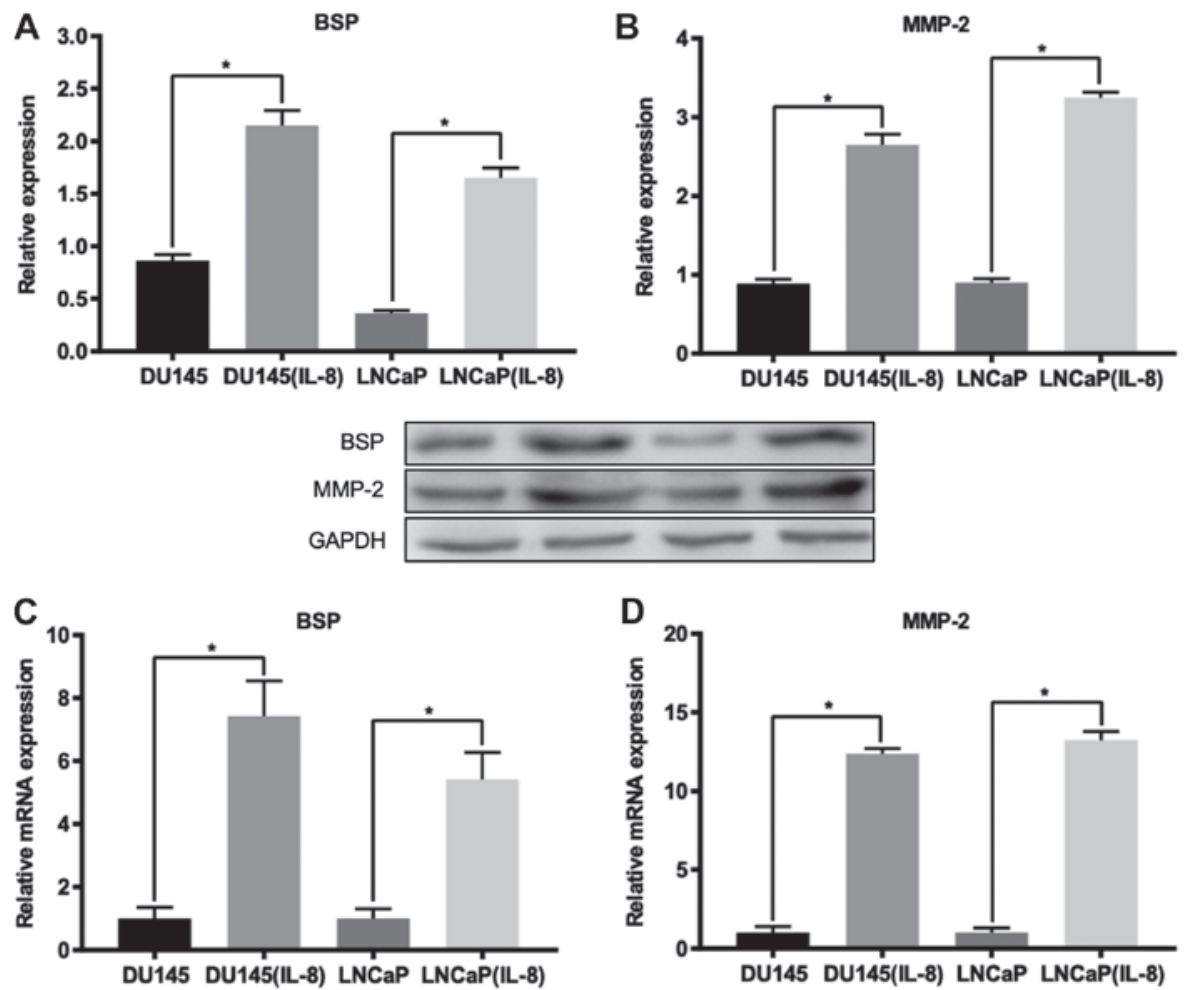

Figure 2. Effect of IL-8 on BSP and MMP-2 protein and mRNA expressions. Western blotting of (A) BSP and (B) MMP-2 protein expression levels in the two PCa cell lines following $48 \mathrm{~h}$ of IL-8 treatment. Detection of the mRNA expression levels of (C) BSP and (D) MMP-2 in the two PCa cell lines after $48 \mathrm{~h}$ of IL-8 treatment. GAPDH served as the internal control. "P<0.05. IL-8, interleukin-8; BSP, bone sialoprotein; MMP-2, matrix metallopeptidase-2; PCa, prostate cancer.
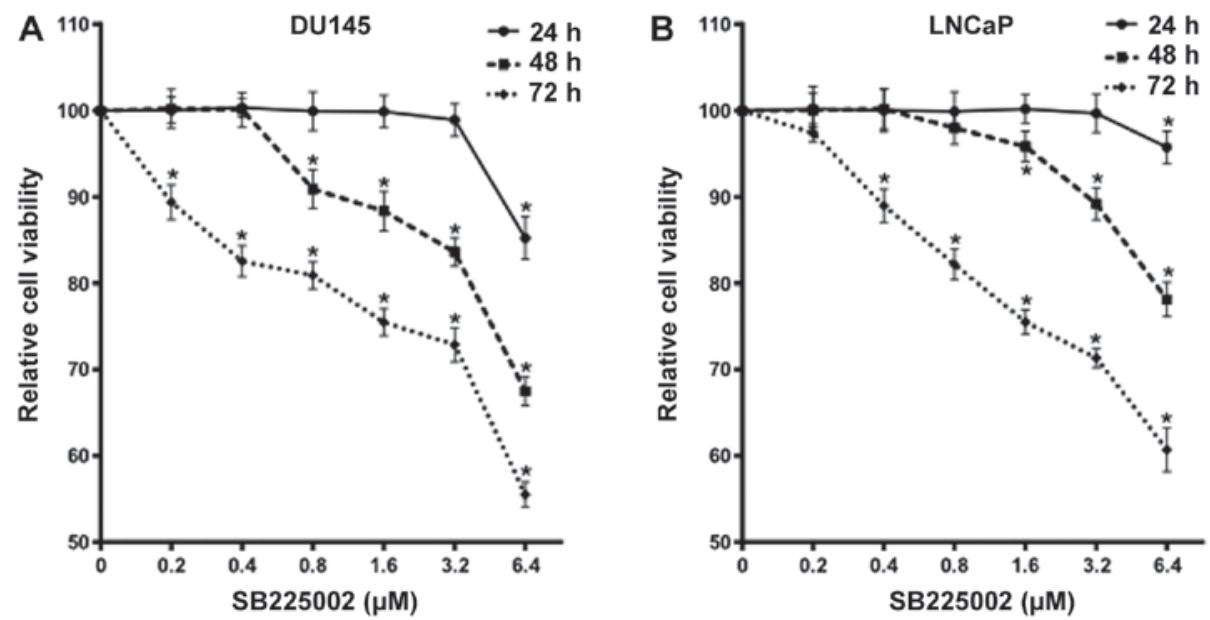

Figure 3. MTT assay of the vitality of the two prostate cancer cell lines following SB225002 treatment. (A) Viability curve of DU-145 cells. (B) Viability curve of LNCaP cells. BSP, bone sialoprotein. " $\mathrm{P}<0.05$.

number of PCa cells having invaded the Matrigel barrier was lower than in the control group. The cell morphology also changed subsequently to Matrigel crossing (Fig. 5).

BSP expression following SB225002 treatment. The two PCa cell lines were treated with SB225002 $(0.4 \mu \mathrm{mol} / \mathrm{l})$ for $48 \mathrm{~h}$, and BSP and MMP-2 expression levels were determined by western blotting and RT-qPCR. The results demonstrated that SB225002 significantly reduced BSP and MMP2 mRNA and protein levels in the two PCa cell lines compared with the control group (Fig. 6).

\section{Discussion}

The cytokine IL- 8 has been indicated to enhance PCa invasiveness (7-9). The majority of previous studies demonstrated that IL-8 promotes the degradation of extracellular matrix by increasing the expression of MMP-2 and MMP-9 in cancer cells $(8,16-21)$. However, to the best of our knowledge, a limited number of studies have been conducted to investigate the role of IL- 8 in the distant metastasis of PCa. In the present study, by altering the extracellular concentration of IL- 8 and inhibiting IL-8 receptor, it was indicated that IL-8 upregulated 
A

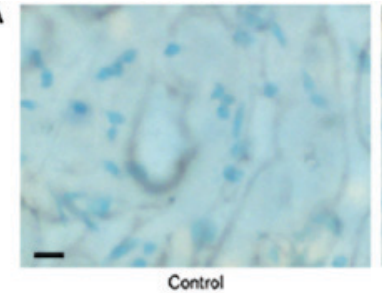

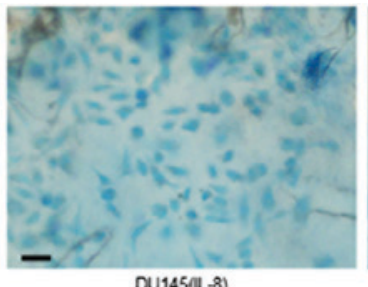

DU145(L-8)
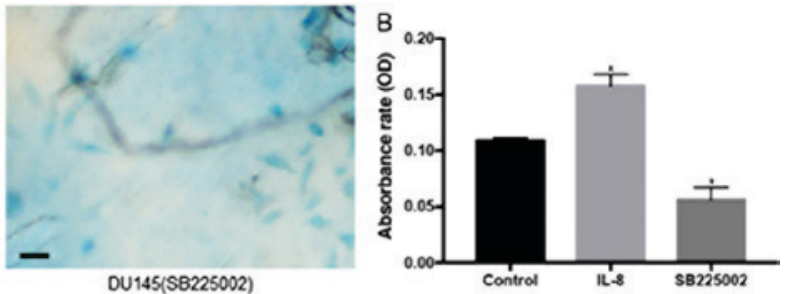

Figure 4. Adhesion of DU-145 on bone chip surfaces following IL-8 and SB225002 treatment (magnification, x400; scale bar, 100 $\mu$ m). (A) Bone chip adhesion assay. The spindle-shaped blue spots on the bone chip are Coomassie brilliant blue-stained DU-145 cells. (B) For all three groups, bone chips were trypsin-digested, and the optical density was determined with a microplate reader at a wavelength of $570 \mathrm{~nm}$. All measurements were performed in triplicate. A significant difference in the IL- 8 group and in the SBS225002 group was observed by analysis of variance followed by Tukey's method. * $<0.05$. IL- 8 , interleukin-8; BSP, bone sialoprotein; OD, optical density.

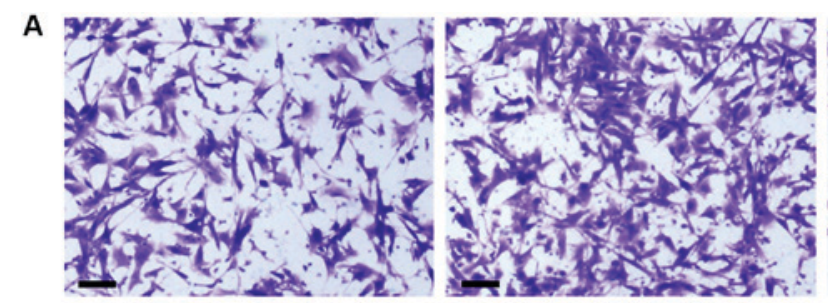

Control

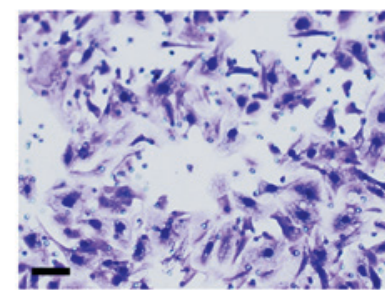

Control

B

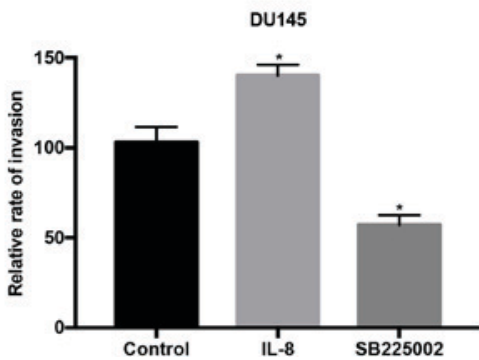

DU145(IL-8)

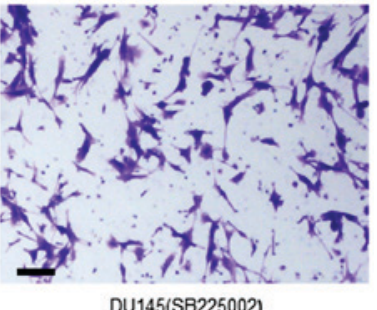

DU145(SB225002)

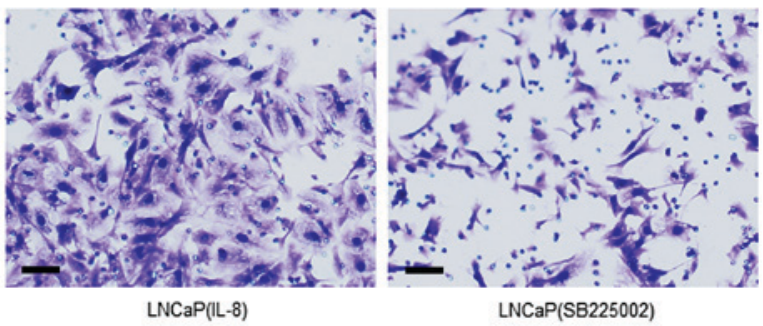

LNCaP

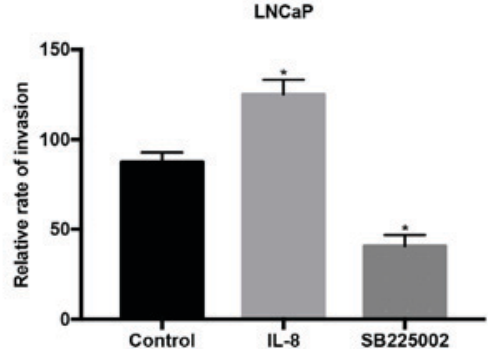

Figure 5. Transwell assays before and after cell treatment with IL-8 and SB225002 (magnification, x400; scale bar, 100 $\mu \mathrm{m}$ ). (A) IL-8 treatment significantly enhanced the invasiveness of DU-145 and LNCaP cells, and the number of invasive cells. SB225002 treatment significantly reduced the invasiveness of DU-145 and LNCaP cells, and the number of invasive cells, in addition to altering cell morphology. (B) The number of invasion cells in DU-145 and LNCaP cells. ${ }^{*} \mathrm{P}<0.05$. IL-8, interleukin-8.

BSP expression. Studies indicated that tumor-secreted BSP aided cancer cells in adhering to bone tissue and growing at metastatic sites $(3,14,22-25)$; therefore, it was concluded that IL-8 promotes bone metastasis of PCa cells via BSP.

BSP is a member of the SIBLING protein family $(6,26-28)$. In the past, researchers considered that BSP is expressed only in mineralized tissues (5), is primarily synthesized by osteoblasts, osteoclasts and chondrocytes (5), and is involved in the metabolism of bone and inorganic salts (4). In 1994, Bellahcène et al (8) demonstrated for the first time that the level of BSP expression was anomalous in human breast cancer and had a tendency to promote bone metastasis (10). Additionally, the serum level of BSP was associated with bone metastases of tumor cells $(8,10)$. Subsequently, a number of studies indicated that BSP serves a notable role in tumor adhesion, proliferation, invasion, matrix degradation, immune response, angiogenesis and metastasis $(5,10,19-21)$. The $\mathrm{N}$-terminus of BSP contains polyglutamic acid, which binds to hydroxyapatite (HA) and has dual regulatory roles in tissue calcification (23). It can also promote HA aggregation to form crystals, in addition to attaching to the surface of HA crystals and affect bone mineralization (24). The C-terminus of BSP has an RGD (Arg-Gly-Asp) tripeptide domain that specifically recognizes and binds to the integrin receptor $\alpha v \beta 3$ on the cell surface (5). Once bound to the integrin receptor, BSP increases the adhesion of tumor cells to other tissues, thereby promoting the attachment of tumor cells to target metastatic organs $(3,5,29)$. During tumor invasion, BSP binds to MMP-2 and regulates its activity $(6,16)$. Once tumor cells reach bone tissue, BSP first activates osteoclasts and subsequently induces MMP-2 to 

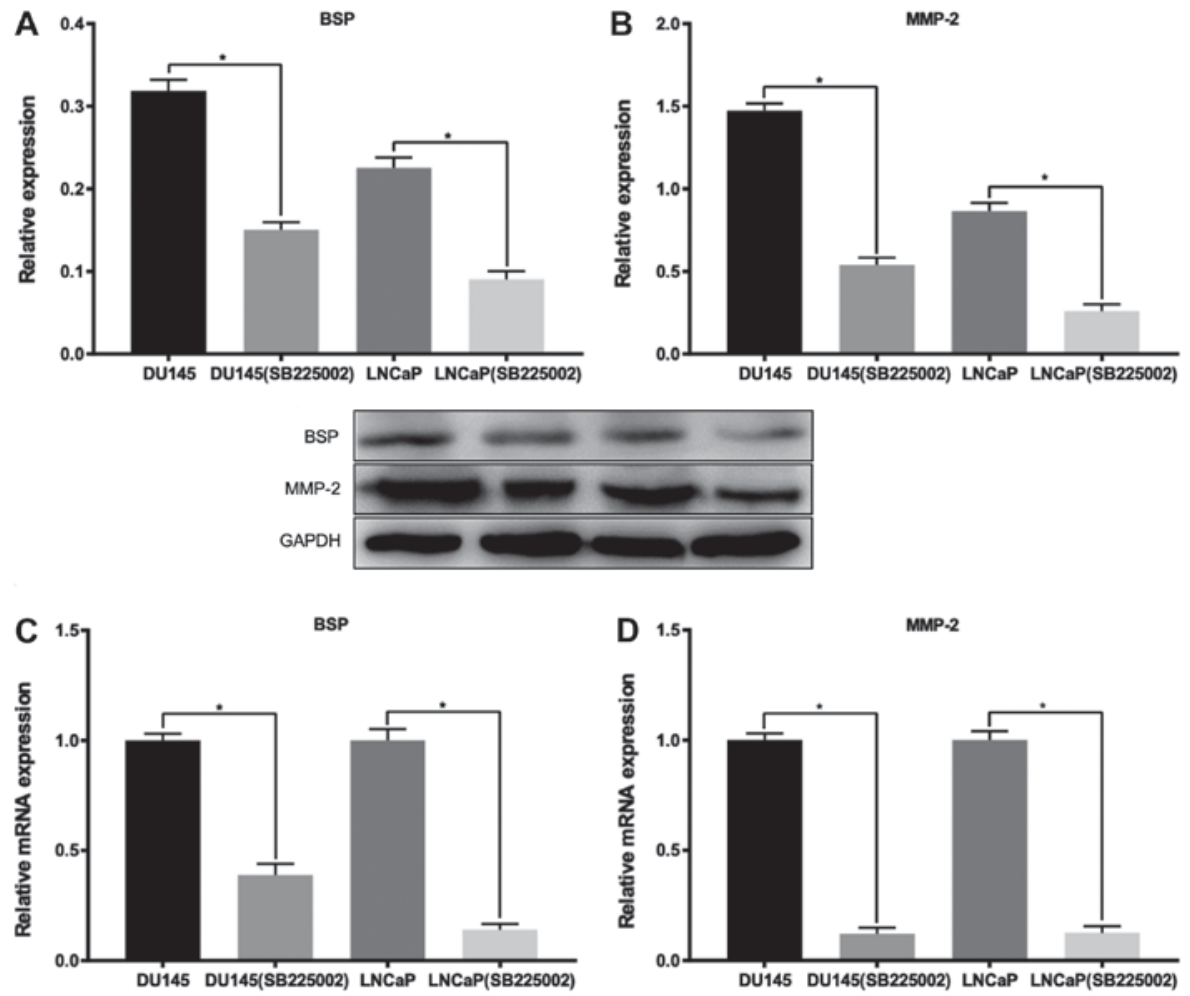

Figure 6. Effect of SB225002 on protein and mRNA expression. Western blotting of (A) BSP and (B) MMP-2 protein expression level in two PCa cell lines after $48 \mathrm{~h}$ of SB225002 treatment. Detection of (C) BSP and (D) MMP-2 mRNA expression levels in the two PCa cell lines after $48 \mathrm{~h}$ of IL-8 treatment. GAPDH served as the internal control. "P<0.05. BSP, bone sialoprotein; MMP-2, matrix metallopeptidase 2; PCa, prostate cancer; IL-8, interleukin-8.

accumulate on the cell surface via $\alpha v \beta 3$, which promotes the osteolytic invasion and metastasis of tumor cells (16). In the present study, western blotting and RT-qPCR indicated that the mRNA and protein expression levels of BSP are significantly increased once recombinant human IL- 8 was added to the medium. Treatment with SB225002, an inhibitor of the IL-8 receptor CXCR2, significantly reduced the number of DU-145 cells (non-androgen-dependent PCa cells) attached to the bone surface, compared with the untreated control group. Matrigel invasion assays further confirmed that the IL-8 receptor inhibitor SB225002 reduced the invasiveness of PCa cells. Additionally, western blotting indicated that SB225002 reduces BSP expression in the two assayed PCa cell lines. These results indicated that IL-8 may serve an important role in regulating BSP expression in PCa cells. In the present study, the stock concentration of IL-8 used was relatively low. Therefore, MMP-2 was used as an indicator to assure an adequate effect of IL-8 in PCa cells. Following IL-8 or SB225002 treatment, the levels of MMP-2 were determined. If a significant change in MMP-2 level was detected (16,17), the BSP level was assessed to ensure that any change in BSP expression in the cells was caused by the experimental treatment.

Bone metastasis is the leading cause of mortality in patients with PCa (3). Tumor cells that metastasize to bone tissue, and attach and grow on bone surfaces can disrupt bone metabolism (4-7). Molecular markers of bone metabolism are metabolites released into the circulation during bone absorption or synthesis in the body (12). Therefore, the level of these markers in the blood or urine can indicate the level of bone metabolism $(4,9,19)$. BSP is an osteolytic marker, and its serum level is an important indicator for the diagnosis of bone metastasis of $\mathrm{PCa}$, with a high BSP level being a predictive risk factor for bone metastasis $(4,10,23)$. The present study indicated that IL-8 is an important factor for BSP expression in PCa cells. In conclusion, IL-8 and BSP are predictors of distant metastasis of PCa (17,30), and IL-8 may become a biological target for the treatment of bone metastasis of $\mathrm{PCa}$, which may serve a significant role in extending the survival time of patients with $\mathrm{PCa}$.

The present study confirmed that IL- 8 affected PCa cell invasion and bone adhesion by upregulating BSP expression levels. IL-8 receptor antagonists may have the ability to downregulate BSP expression levels and inhibit PCa cell invasion and bone adhesion.

\section{Acknowledgements}

The authors would like to thank Professor Huamao Jiang (Department of Urology, The First Affiliated Hospital of Jinzhou Medical University) for his technical guidance for this experiment.

\section{Funding}

The present study was supported by the Liaoning BaiQianWan Talents Program and the Distinguished Professor Fund of the Liaoning Provincial Department of Education (LiaoJiaoFa 2015; grant no. 153).

\section{Availability of data and materials}

The datasets analyzed during the current study are available from the corresponding author on reasonable request. 


\section{Authors' contributions}

$\mathrm{HJ}$ and BL conceived and designed the study. BL, MX, JL, ZG and $\mathrm{XC}$ performed the experiments. BL wrote the paper. $\mathrm{HJ}$ and $\mathrm{BL}$ reviewed and edited the manuscript. All authors read and approved the manuscript and ensured that the accuracy or integrity of any part of the work were appropriately investigated and resolved.

\section{Ethics approval and consent to participate}

The animal experiment was approval by the JinZhou University Laboratory Animal Ethics Review Committee (JinZhou, China).

\section{Patient consent for publication}

Not applicable.

\section{Competing interests}

The authors declare that they have no competing interests.

\section{References}

1. Chen K, Wu K, Jiao X, Wang L, Ju X, Wang M, Di Sante G, Xu S, Wang Q, Li K, et al: The endogenous cell-fate factor dachshund restrains prostate epithelial cell migration via repression of cytokine secretion via a CXCL signaling module. Cancer Res 75 : 1992-2004, 2015.

2. Siegel RL, Miller KD and Jemal A: Cancer statistics, 2016. Ca Cancer J Clin 54: 8-29, 2015.

3. Chaplet M, Waltregny D, Detry C, Fisher LW, Castronovo V and Bellahcène A: Expression of dentin sialophosphoprotein in human prostate cancer and its correlation with tumor aggressiveness. Int J Cancer 118: 850-856, 2006.

4. Sung V, Cattell DA, Bueno JM, Murray A, Zwiebel JA, Aaron AD and Thompson EW: Human breast cancer cell metastasis to long bone and soft organs of nude mice: A quantitative assay. Clin Exp Metastasis 15: 173-183, 1997.

5. Bellahcène A, Castronovo V, Ogbureke KU, Fisher LW and Fedarko NS: Small integrin-binding ligand N-linked glycoproteins (SIBLINGs): Multifunctional proteins in cancer. Nat Rev Cancer 8: 212-226, 2008.

6. Anunobi CC, Koli K, Saxena G, Banjo AA and Ogbureke KU: Expression of the SIBLINGs and their MMP partners in human benign and malignant prostate neoplasms. Oncotarget 7: 48038-48049, 2016

7. Inoue K, Slaton JW, Eve BY, Kim SJ, Perrotte P, Balbay MD, Yano S, Bar-Eli M, Radinsky R, Pettaway CA and Dinney CP: Interleukin 8 expression regulates tumorigenicity and metastases in androgen-independent prostate cancer. Clin Cancer Res 6: 2104-2119, 2000.

8. Bellahcène A, Merville MP and Castronovo V: Expression of bone sialoprotein, a bone matrix protein, in human breast cancer. Cancer Res 54: 2823-2826, 1994.

9. Neveu B, Moreel X, Deschênes-Rompré MP, Bergeron A, LaRue H, Ayari C, Fradet Y and Fradet V: IL-8 secretion in primary cultures of prostate cells is associated with prostate cancer aggressiveness. Res Reports Urol 2014: 27-34, 2014.

10. Michaud DS, Daugherty SE, Berndt SI, Platz EA, Yeager M, Crawford ED, Hsing A, Huang WY and Hayes RB: Genetic polymorphisms of interleukin-1B (IL-1B), IL-6, IL-8, and IL-10 and risk of prostate cancer. Cancer Res 66: 4525-4530, 2016.

11. Goda AE, Koyama M, Sowa Y, Elokely KM, Yoshida T, Kim BY and Sakai T: Molecular mechanisms of the antitumor activity of SB225002: A novel microtubule inhibitor. Biochem Pharmacol 85: 1741-1752, 2013.

12. Hamilton SL, Ferando B, Eapen AS, Yu JC and Joy AR: Cancer secretome may influence BSP and DSP expression in human salivary gland cells. J Histochem Cytochem 65: 139-151, 2017.
13. de Vasconcellos JF, Laranjeira AB, Leal PC, Bhasin MK, Zenatti PP, Nunes RJ, Yunes RA, Nowill AE, Libermann TA, Zerbini LF and Yunes JA: SB225002 induces cell death and cell cycle arrest in acute lymphoblastic leukemia cells through the activation of GLIPR1. PLoS One 10: e0134783, 2015.

14. Du M, Qiu Q, Gruslin A, Gordon J, He M, Chan CC, Li D and Tsang BK: SB225002 promotes mitotic catastrophe in chemo-sensitive and -resistant ovarian cancer cells independent of p53 status in vitro. PLoS One 8: e54572, 2013.

15. Livak KJ and Schmittgen TD: Analysis of relative gene expression data using real-time quantitative PCR and the 2(-Delta Delta C(T)) method. Methods 25: 402-408, 2001.

16. Xu M, Jaing H, Wang H, Liu J, Liu B and Guo Z: SB225002 inhibits prostate cancer invasion and attenuates the expression of BSP, OPN and MMP-2. Oncol Rep 40: 726-736, 2018.

17. Tu Q, Zhang J, Fix A, Brewer E, Li YP, Zhang ZY and Chen J: Targeted overexpression of BSP in osteoclasts promotes bone metastasis of breast cancer cells. J Cell Physiol 218: 135-145, 2009.

18. Luca M, Huang S, Gershenwald JE, Singh RK, Reich R and Bar-Eli M: Expression of interleukin-8 by human melanoma cells up-regulates MMP-2 activity and increases tumor growth and metastasis. Am J Pathol 151: 1105-1113, 1997.

19. Pold M, Zhu LX, Sharma S, Burdick MD, Lin Y, Lee PP, Põld A, Luo J, Krysan K, Dohadwala M, et al: Cyclooxygenase-2 dependent expression of angiogenic CXC chemokines, ENA-78/CXC Ligand (CXCL) 5 and interleukin-8/CXCL8, in human non-small cell lung cancer. Cancer Res 64: 1853-1860, 2004.

20. Mahboob S, Ahn SB, Cheruku HR, Cantor D, Rennel E, Fredriksson S, Edfeldt G, Breen EJ, Khan A, Mohamedali A, et al: A novel multiplexed immunoassay identifies CEA, IL-8 and prolactin as prospective markers for Dukes' stages A-D colorectal cancers. Clin Proteomics 12: 10, 2015.

21. Freund A, Chauveau C, Brouillet JP, Lucas A, Lacroix M, Licznar A, Vignon F and Lazennec G: IL-8 expression and its possible relationship with estrogen-receptor-negative status of breast cancer cells. Oncogene 22: 256-265, 2003.

22. Jain A, Mcknight DA, Fisher LW, Humphreys EB, Mangold LA, Partin AW and Fedarko NS: Small integrin-binding proteins as serum markers for prostate cancer detection. Clin Cancer Res 15: 5199-5207, 2009.

23. Zhang JH, Tang J, Wang J, Ma W, Zheng W, Yoneda T and Chen J: Over-expression of bone sialoprotein enhances bone metastasis of human breast cancer cells in a mouse model. Int J Oncol 23: 1043-1048, 2003

24. Gordon JA, Sodek J, Hunter GK and Goldberg HA: Bone sialoprotein stimulates focal adhesion-related signaling pathways: Role in migration and survival of breast and prostate cancer cells. J Cell Biochem 107: 1118-1128, 2009.

25. Wang J, Wang L, Xia B, Yang C, Lai H and Chen X: BSP gene silencing inhibits migration, invasion, and bone metastasis of MDA-MB-231BO human breast cancer cells. PLoS One 8: e62936, 2013.

26. Zhang JH, Wang J, Tang J, Barnett B, Dickson J, Hahsimoto N, Williams P, Ma W, Zheng W, Yoneda T, et al: Bone sialoprotein promotes bone metastasis of a non-bone-seeking clone of human breast cancer cells. Anticancer Res 24: 1361-1368, 2004.

27. Wei RJ, Li TY, Yang XC, Jia N, Yang XL and Song HB: Serum levels of PSA, ALP, ICTP, and BSP in prostate cancer patients and the significance of ROC curve in the diagnosis of prostate cancer bone metastases. Genet Mol Res: 15, 2015.

28. Riminucci M, Corsi A, Peris K, Fisher LW, Chimenti S and Bianco P: Coexpression of bone sialoprotein (BSP) and the pivotal transcriptional regulator of osteogenesis, Cbfa1/Runx2, in malignant melanoma. Calcif Tissue Int 73: 281-289, 2003.

29. Bellahcène A, Bonjean K, Fohr B, Fedarko NS, Robey FA, Young MF, Fisher LW and Castronovo V: Bone sialoprotein mediates human endothelial cell attachment and migration and promotes angiogenesis. Circ Res 86: 885-891, 2000.

30. Righi L, Bollito E, Ceppi P, Mirabelli D, Tavaglione V, Chiusa L, Porpiglia F, Brunelli M, Martignoni G, Terrone C and Papotti M: Prognostic role of bone sialoprotein in clear cell renal carcinoma. Anticancer Res 33: 2679-2687, 2013.

(i) (3) This work is licensed under a Creative Commons Attribution-NonCommercial-NoDerivatives 4.0 International (CC BY-NC-ND 4.0) License. 